\title{
The Impact of Governance Structure on R \& D Investment in Chinese Listed Family Firms under the Institutional Environment of Marketization
}

\author{
Jun Kong1,2, Yan Gao1, Fan Jiang ${ }^{3}$ \\ ${ }^{1}$ School of Economics and Management, Northwest University, Xi'an, China \\ ${ }^{2}$ Westchina Economic and Development Center, Xi'an, China \\ ${ }^{3}$ Department of Economics, Texas Tech University, Lubbock, Texas, USA \\ Email: 544790789@qq.com
}

How to cite this paper: Kong, J., Gao, Y. and Jiang, F. (2019) The Impact of Governance Structure on $\mathrm{R} \& \mathrm{D}$ Investment in Chinese Listed Family Firms under the Institutional Environment of Marketization. Open Journal of Social Sciences, 7, 243-254.

https://doi.org/10.4236/jss.2019.73021

Received: February 28, 2019

Accepted: March 10, 2019

Published: March 13, 2019

\begin{abstract}
The Pooled OLS model is used to analyze whether governance structure such as family ownership, management, and control can actually influence R \& D investment in Chinese family firms by application of the listed companies from the CSMAR database. After controlling for size, debt, age, profitability and growth, the positive impacts of family ownership and family management on $\mathrm{R} \& \mathrm{D}$ and the negative impact of family control on $\mathrm{R} \& \mathrm{D}$ are found. The other research question explored is whether the moderating effects of institution environment exist in the sample. Institution environment variable and its intersection terms with governance structure are added to the models respectively. Meanwhile, the positive impacts of family ownership and family management on R \& D are weaker while the negative impact of family control is weaker provincially in a better institution environment. Regarding the institution environment itself, it shows a consistent positive impact on $\mathrm{R}$ $\& \mathrm{D}$ investment. Meanwhile a substitution effect between the institution environment and the family governance structure is found.
\end{abstract}

\section{Keywords}

Ownership, Management, Control, R \& D, Institution Environment

\section{Introduction}

$\mathrm{R} \& \mathrm{D}$ investment is considered as the fundamental decision in firms' innovation around the world [1]. It advances product, technology and then helps firms to be more market competitive and profitable [2] [3]. Because of the important role of 
R \& D investment to firms' innovation, main stream of R \& D investment studies have examined the determinants of firm's $\mathrm{R} \& \mathrm{D}$ investment. The factors that can influence firm's R \& D investment include but not limited to industry choice [4], firm size [5] [6], firm strategy [7] [8], CEO characteristics [3] [4] and firm's financial status [9] [10]. The most complicated but important determinant of $\mathrm{R} \& \mathrm{D}$ investment is firm governance structure since it links R \& D investment to agency problems [1].

Existing literatures have noticed the impact of firm ownership types [11], ownership concentration [12] and board independence [13] on R \& D investment in normal firms. However, given the fact that family firms are dominant in most economies in the world today, especially in Asian countries [14] [15] and family business studies have verified the great contribution of family firms to innovation and economic growth [16], whether the governance structure can actually affect R \& D investment in family firm is still short of research. Moreover, governance structure in family firm varies in modes of family involvement. Although previous studies point out major governance characteristics in family firm are family ownership [15] [17], family management [18] and family control [19], they fail to clarify these concepts and there is no complete analysis including all three dimensions in family firm. Additionally, institution environment deserves more attentions for investigating the impacts of family ownership, management and control on R \& D investment of family firms. Steier (2009) and Liu et al. (2012) indicate that family firms have different operation strategies under different institution environments [20] [21].

Chinese economy currently shows a huge demand for studies about R \& D investment in family firms. After 2004, more state owned enterprises have been turning to be family firms since private ownership has higher incentive to innovate and develop. Due to the comparative advantage in cheap production factors such as labor and land, Chinese family firms transfer from manufacturer to innovator in the future and improve governance quality. Furthermore, as a transition economy, the institution development in China has significant regional difference. Specifically, southeastern area and coastal provinces in China have built better institution systems, such as effective government intervention, stronger legal protection and enforcement and available financial market accessibility. The regional disparity in institution environments may play a key role on family firm strategic actions like R \& D investment.

Overall, this paper contributes to the literature by investigating the impacts of governance structure on $\mathrm{R} \& \mathrm{D}$ investment in Chinese family firms. First I use family ownership, management and control to provide clear dimensions of family involvement in governance structure. Then I develop the hypothesis by matching family ownership, management and control with $\mathrm{R} \& \mathrm{D}$ investment through agency theory. There are two agency problems documented here. The leading one is principal-agent conflicts between owner (the principal) and manager (the agent) [22]. Long term oriented owner prefers to invest more on R \& D for high expected future benefits and gaining more external monitoring by the 
market to reduce managers' opportunistic behaviors. The alternative agency problem is controlling-minority shareholder conflicts, also be called principal-principal conflict [23] [24] [25] [26]. Given the facts that family controlling shareholder may takes advantage of the controlling position to extract private benefits from minority shareholders, minority shareholders may discount and refuse to invest in R \& D proposed by family controlling shareholder. Dispersed ownership has a larger propensity to cause principal-agent conflict while concentrated ownership increases the likelihood of principal-principal conflict in $\mathrm{R}$ \& D investment. Based on 4773 Chinese listed firm data from 2004 to 2012, the estimation results show that family ownership and family management have a positive impact on R \& D investment; on contrary, family control has a negative impact on R \& D investment.

This paper further explores the moderating effects of institution environment by adding the marketization index of 31 provinces in China to the regression models. The results indicate that better institution environment alleviates the negative relationship between family ownership and R \& D investment, and verifying that better institution environment reinforces family management's positive influence on R \& D investment. At last, our evidence supports that the negative relationship between family control and $\mathrm{R} \& \mathrm{D}$ investment is weaker for firms in regions with better institutions environment.

The rest of this paper is organized as follows. Section 2 develops hypothesis on the impact of family ownership, management and control on R \& D investment in Chinese family firms; then develop the hypothesis of the moderating effects of institutions environment. Section 3 describes the data selection, variable definitions. Section 4 is empirical methods, descriptive statistics and regression results. Section 5 is conclusion.

\section{Hypothesis Development}

Based on Section one, I propose the competing hypotheses on the relationship between family ownership and R \& D investment as follows:

H1a: Family ownership has a negative impact on R \& D investment.

H1b: Family ownership has a positive impact on $R \& D$ investment

H2a: Family management has a positive impact on $\mathrm{R} \& \mathrm{D}$ investment.

H2b: Family management has a negative impact on R \& D investment.

H3: Family control has a negative impact on $\mathrm{R} \& \mathrm{D}$ investment.

H4a: The negative relationship between family ownership and R \& D investment is weaker for firms in regions with better institutions environment.

H4b: The positive relationship between family ownership and R \& D investment is weaker for firms in regions with better institutions environment.

H5a: The positive relationship between family management and R \& D investment is weaker for firms in regions with better institutions environment.

H5b: The negative relationship between family management and R \& D investment is weaker for firms in regions with better institutions environment.

H6: The negative relationship between family control and R \& D investment is 
weaker for firms in regions with better institutions environment.

\section{Research Design}

\subsection{Data}

The sample has two data sources. One source of data is from China Stock Market \& Accounting Research (CSMAR) Database. The data covers Shanghai and Shenzhen stock exchanges between 2004 and 2012. First, I directly extract stock code, report date, total assets, listed date, total debt, return to asset ratio, sales growth rate, total employees, location, industry, total share outstanding and family ownership. Then, sample family firm with a family member as the CEO is coded as 1 , and 0 otherwise; family firm with a pyramid structure is coded as 1 , and 0 otherwise. At last, check the year books of those sample family firms one by one to see if they have R \& D investment data because R \& D investment data is not a mandatory data for public disclosure. After the above three steps, 4773 family firm observations are recorded. The other source of data is province marketization index data from Fan et al., (2011). However, the available data only covers from 2004 to 2009. Given the fact that 2010, 2011 and 2012 data counts for about $55 \%$ of sample family firms and it would be a big loss to drop them, I use ARIMA models and 2004 to 2009 marketization index data to forecast the data for 31 provinces in China from 2010 to 2012. The forecast is not reported here but available for inquiry. The target data set of this paper is finally generated by matching the marketization data with family firm data by provinces.

\subsection{Variable Description}

$\mathrm{R} \& \mathrm{D}$ intensity is dependent variable in regression models. It's measured as the ratio of $\mathrm{R} \& \mathrm{D}$ expenditures to the total assets following the standard analysis. In this paper, three independent variables, family ownership, family management and family control, are discussed. Family ownership is the number of shares held by family members divided by the total shares outstanding. Family management is a dummy variable which is coded as 1 if a family member as the CEO, and otherwise. Family control is a dummy variable as well, coded as 1 if the firm has a pyramid structure and otherwise.

Five control variables and one moderator are considered in this paper. Firm size is controlled and measured as the logarithm of the number of employees. Debt is controlled and measured as the ratio of total debt to total assets. Age is measured as the logarithm of the years that family firm had been in existence. Profitability is measured as return on assets. Growth is measured as percentage annual growth of sales. Moderator is institution environment which is measured as marketization index for 31 provinces.

\section{Empirical Analysis and Results}

\subsection{Descriptive Statistics}

Figure 1 shows sample family firm numbers in different years. From percentage 


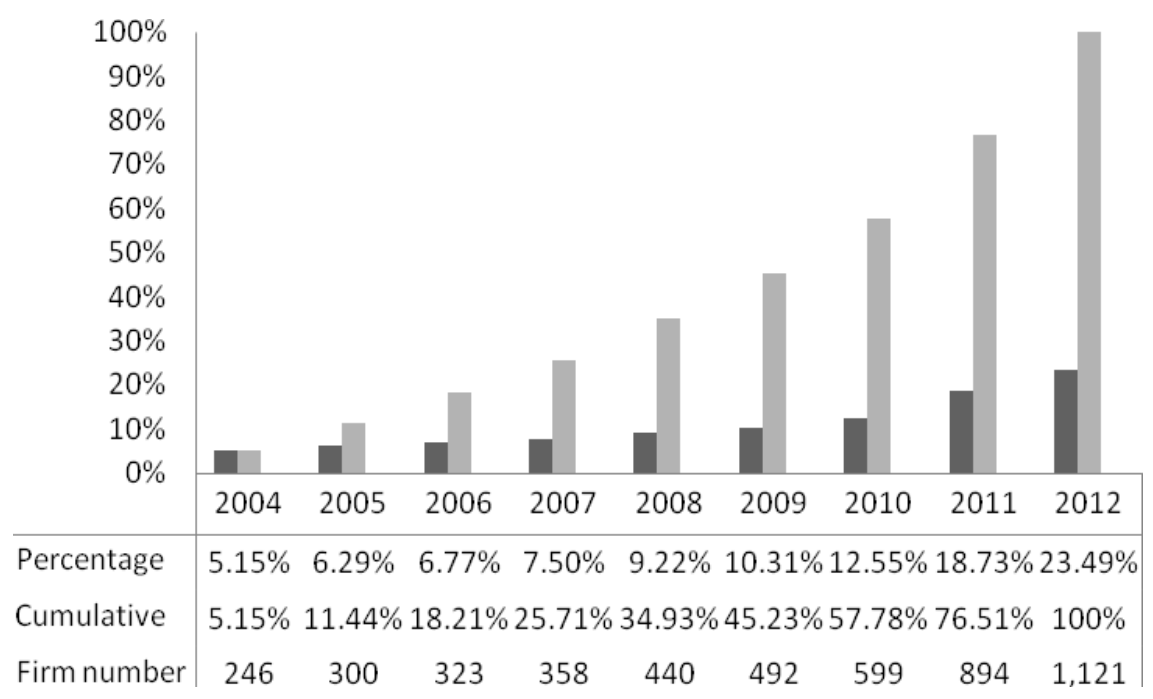

Figure 1. Statistical example of sample family firm numbers in different years.

perspective, quantity of family firm in my sample gradually goes up as time passes. Family firms in 2004 which counts for $5.15 \%$ is the minimum group while the ones in 2012 which counts for $23.49 \%$ is the maximum group. From cumulative perspective, seven years sample group from 2004 to 2010 only counts for $57.78 \%$ of total sample size. Year 2011 and 2012 samples take a large weight, almost $45 \%$. In addition, family firm numbers are not graphed in Figure 1 but reported underneath. It clearly presents an upward trend of family firm numbers across years.

Figure 2 illustrates the industry distribution of sample family firms. Industry C which counts for $64.8 \%$ of sample size has the largest group of family firms conducting R \& D investment. Industry G which counts for $9.74 \%$ takes the second place. Industry J, $\mathrm{M}$ and $\mathrm{H}$, count for $5.49 \%$. 5.24\% and $4.57 \%$ respectively, also take considerable weights in my sample. Industry D, B and L, count for $0.78 \%, 0.69 \%$ and $0.65 \%$ respectively, are the bottom three industries which have the minimum family firms investing $\mathrm{R} \& \mathrm{D}$.

Table 1 describes the province ranking of family firms conducting $R \& D$ investment. Guangdong, Zhejiang and Jiangsu, which are southern provinces and considered as the most developed areas in China, rank top three in family firm numbers while Guizhou, Ningxia and Qinghai, which are located in inner land and known as provinces of poverty, hold the bottom three. Top three provinces count $43.6 \%$ of total family firms. On contrary, bottom three provinces only count $1.6 \%$. There is a huge gap between inner land provinces and southern provinces in family firm numbers conducting $\mathrm{R} \& \mathrm{D}$ investment.

Table 2 presents descriptive statistics and measures of all variables. The average R \& D intensity of sample family firms is 0.0183 . Family firms also hold $36 \%$ in average ownership. It's expected that about $65 \%$ family firms have family $\mathrm{CEO}$ and $76 \%$ family firms have pyramid structures. For control variables, average firm size is about 610 employees and average firm age is about 13 years 
Percentage

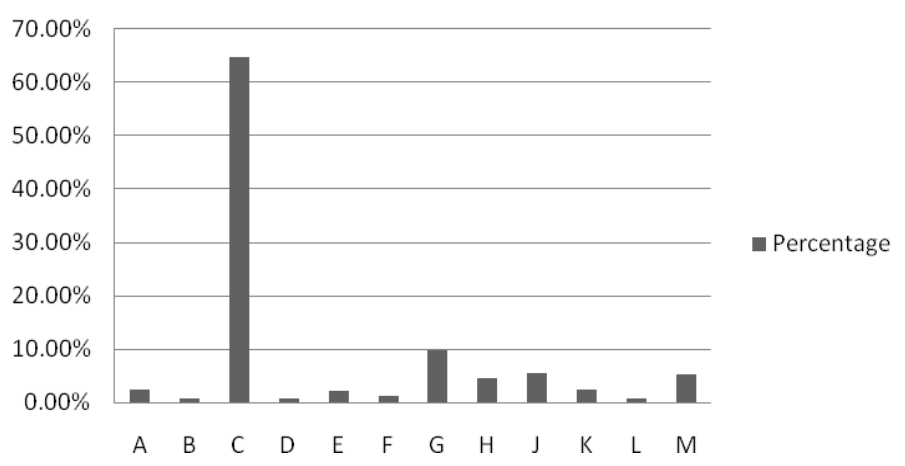

Figure 2. Industrial distributions of sample family firms.

Table 1. Province distributions of sample family firms.

\begin{tabular}{|c|c|c|c|}
\hline Province Rank & Family Firm numbers & Percentage & Cumulative \\
\hline Guangdong & 810 & 17.0 & 17.0 \\
\hline Zhejiang & 742 & 15.6 & 32.5 \\
\hline Jiangsu & 527 & 11.0 & 43.6 \\
\hline Shandong & 259 & 5.4 & 49.0 \\
\hline Shanghai & 235 & 4.9 & 53.9 \\
\hline Beijing & 229 & 4.8 & 58.7 \\
\hline Sichuan & 215 & 4.5 & 63.2 \\
\hline Fujian & 187 & 3.9 & 67.1 \\
\hline Hubei & 183 & 3.8 & 71.0 \\
\hline Anhui & 127 & 2.7 & 73.6 \\
\hline Liaoning & 125 & 2.6 & 76.2 \\
\hline Hunan & 117 & 2.5 & 78.7 \\
\hline Henan & 91 & 1.9 & 80.6 \\
\hline Hainan & 86 & 1.8 & 82.4 \\
\hline Jilin & 85 & 1.8 & 84.2 \\
\hline Hebei & 84 & 1.8 & 85.9 \\
\hline Guangxi & 70 & 1.5 & 87.4 \\
\hline Xinjiang & 63 & 1.3 & 88.7 \\
\hline Heilongjiang & 59 & 1.2 & 90.0 \\
\hline Gansu & 50 & 1.1 & 91.0 \\
\hline Neimeng & 50 & 1.1 & 92.1 \\
\hline Chongqing & 50 & 1.1 & 93.1 \\
\hline Shaanxi & 45 & 0.9 & 94.1 \\
\hline Xizang & 45 & 0.9 & 95.0 \\
\hline Shanxi & 42 & 0.9 & 95.9 \\
\hline Tianjin & 42 & 0.9 & 96.8 \\
\hline Yunnan & 41 & 0.9 & 97.6 \\
\hline Jiangxi & 37 & 0.8 & 98.4 \\
\hline Guizhou & 33 & 0.7 & 99.1 \\
\hline Ningxia & 25 & 0.5 & 99.6 \\
\hline Qinghai & 19 & 0.4 & 100.0 \\
\hline 31Provinces Total & 4773 & 100 & \\
\hline
\end{tabular}


Table 2. Statistics and measures of variables.

\begin{tabular}{|c|c|c|c|c|c|}
\hline Variables & Type & $\mathrm{N}$ & Mean & SD & Measurement \\
\hline $\mathrm{RD}$ & $\begin{array}{l}\text { Dependent } \\
\text { Variable }\end{array}$ & 4773 & 0.0183 & 0.0317 & $\begin{array}{l}\text { measured as the ratio of } \\
\mathrm{R} \& \mathrm{D} \text { expenditures } \\
\text { to the total assets }\end{array}$ \\
\hline $\begin{array}{c}\text { Family } \\
\text { Ownership }\end{array}$ & $\begin{array}{l}\text { Independent } \\
\text { Variable }\end{array}$ & 4773 & 0.3609 & 0.1518 & $\begin{array}{l}\text { measured as the number of shares } \\
\text { held by family members divided } \\
\text { by the total shares outstanding }\end{array}$ \\
\hline $\begin{array}{c}\text { Family } \\
\text { Management }\end{array}$ & $\begin{array}{l}\text { Independent } \\
\text { Variable }\end{array}$ & 4773 & 0.6539 & 0.4758 & $\begin{array}{l}\text { family firm with a family member } \\
\text { as the CEO is coded as } 1 \text {, } \\
\text { and } 0 \text { otherwise [19] }\end{array}$ \\
\hline $\begin{array}{l}\text { Family } \\
\text { Control }\end{array}$ & $\begin{array}{l}\text { Independent } \\
\text { Variable }\end{array}$ & 4773 & 0.7637 & 0.4249 & $\begin{array}{l}\text { family firm with a pyramid } \\
\text { structure is coded as } \\
1 \text {, and } 0 \text { otherwise [19] }\end{array}$ \\
\hline Institution & Moderator & 4773 & 9.1722 & 2.0667 & measured as marketization index \\
\hline Size & $\begin{array}{l}\text { Control } \\
\text { Variable }\end{array}$ & 4773 & 7.0476 & 1.2318 & $\begin{array}{l}\text { measured as the logarithm } \\
\text { of the number of employees }\end{array}$ \\
\hline Debt & $\begin{array}{l}\text { Control } \\
\text { Variable }\end{array}$ & 4773 & 0.4526 & 0.2786 & $\begin{array}{l}\text { measured as the ratio of total } \\
\text { debt to total assets }\end{array}$ \\
\hline Age & $\begin{array}{l}\text { Control } \\
\text { Variable }\end{array}$ & 4773 & 2.5779 & 0.3494 & $\begin{array}{l}\text { measured as the logarithm } \\
\text { of the years that family firm } \\
\text { had been in existence [16] }\end{array}$ \\
\hline Profitability & $\begin{array}{l}\text { Control } \\
\text { Variable }\end{array}$ & 4773 & 0.0487 & 0.0761 & measured as return on assets \\
\hline Growth & $\begin{array}{l}\text { Control } \\
\text { Variable }\end{array}$ & 4773 & 0.2361 & 1.0176 & $\begin{array}{l}\text { measured as percentage } \\
\text { annual growth of sales }\end{array}$ \\
\hline
\end{tabular}

(these two numbers are reported in logarithm form in Table 2). Average debt is 0.2786 , average profitability is 0.0761 and average growth $1.02 \%$. Average marketization index, marked as institution, is 9.1722 for 31 provinces in China. Table 3 reports the correlations of variables used for my analysis. Family ownership and family management turn to be positively correlated with $\mathrm{R} \& \mathrm{D}$ while family control has a positive one. They provide some indications for the directions of hypothesized impacts. The correlation between family ownership and family management is positive and relatively strong as expected. The results that profitability is positively correlated with $\mathrm{R} \& \mathrm{D}$ and debt, age and growth are negatively correlated with $\mathrm{R} \& \mathrm{D}$ are also consistent with intuition. However, size is uncorrelated with $\mathrm{R} \& \mathrm{D}$ in my sample. I find that multicollinearity is not a big issue for my sample and I could add intersection terms to my following regression model.

\subsection{Regression Results}

1) The Impacts of Family Ownership, Management and Control on R \& D Investment.

Table 3 demonstrates the results of three models which discuss the impacts of 
Table 3. The impacts of family ownership, management and control on R \& D investment.

\begin{tabular}{|c|c|c|c|}
\hline Variables & Model 1 & Model 2 & Model 3 \\
\hline Family Ownership & $\begin{array}{c}0.007^{* * *} \\
{[2.72]}\end{array}$ & & \\
\hline Family Management & & $\begin{array}{c}0.006^{* * *} \\
{[7.70]}\end{array}$ & \\
\hline Family Control & & & $\begin{array}{c}-0.010^{\star * *} \\
{[-10.70]}\end{array}$ \\
\hline Constant & $\begin{array}{c}0.051^{\star * *} \\
{[8.74]}\end{array}$ & $\begin{array}{c}0.049^{\star * *} \\
{[8.71]}\end{array}$ & $\begin{array}{c}0.054^{\star * *} \\
{[9.64]}\end{array}$ \\
\hline Size & $\begin{array}{c}-0.001^{\star * *} \\
{[-3.93]}\end{array}$ & $\begin{array}{c}-0.002^{* * *} \\
{[-4.67]}\end{array}$ & $\begin{array}{c}-0.001^{\star *} \\
{[-2.54]}\end{array}$ \\
\hline Debt & $\begin{array}{l}-0.024^{\star * *} \\
{[-15.62]}\end{array}$ & $\begin{array}{l}-0.023^{\star * *} \\
{[-14.72]}\end{array}$ & $\begin{array}{l}-0.022^{* * *} \\
{[-14.40]}\end{array}$ \\
\hline Age & $\begin{array}{c}-0.014^{\star * *} \\
{[-11.80]}\end{array}$ & $\begin{array}{c}-0.013^{* * *} \\
{[-11.58]}\end{array}$ & $\begin{array}{c}-0.012^{\star * *} \\
{[-10.96]}\end{array}$ \\
\hline Profitability & $\begin{array}{l}0.008 \\
{[1.44]}\end{array}$ & $\begin{array}{c}0.008 \\
{[1.36]}\end{array}$ & $\begin{array}{c}0.008 \\
{[1.45]}\end{array}$ \\
\hline Growth & $\begin{array}{l}-0.001^{*} \\
{[-1.94]}\end{array}$ & $\begin{array}{c}-0.001^{\star *} \\
{[-2.02]}\end{array}$ & $\begin{array}{c}-0.001^{\star} \\
{[-1.71]}\end{array}$ \\
\hline $\mathrm{N}$ & 4773 & 4773 & 4773 \\
\hline F-value & 121.57 & 124.97 & 128.59 \\
\hline R Square & 0.390 & 0.397 & 0.404 \\
\hline Adjusted R Square & 0.387 & 0.394 & 0.401 \\
\hline
\end{tabular}

Note: ${ }^{\star}{ }^{* \star},{ }^{* *}$ represent significant results associated with $\mathrm{P}<0.1, \mathrm{P}<0.05$, and $\mathrm{P}<0.01$.

family ownership, management and control on R \& D Investment respectively. All the models control for size, debt, age, profitability and growth and are estimated by pooled OLS (fixed effects models are also estimated and obtained similar results). In model 1, family management and family control are excluded and the independent variable is family ownership. The regression result shows that family ownership has a positive impact on R \& D. Coefficient is 0.007 and statistically significant $(\mathrm{P}<0.01)$ so that $\mathrm{H} 1 \mathrm{~b}$ is supported. Model 1 also suggests that size, debt, age and growth all have negative impacts on $\mathrm{R} \& \mathrm{D}$ under different significance thresholds. The profitability is not significant in this model. Model 1 explains 39\% of R \& D intensity differences between sample family firms. In model 2, family management is the only independent variable. The regression result supports $\mathrm{H} 2 \mathrm{a}$ and suggests that family firm with family $\mathrm{CEO}$ increases R \& D intensity by 0.006 . Similar results for control variables, size, debt, age and growth all have negative impacts on $\mathrm{R} \& \mathrm{D}$ under different significance thresholds, whereas insignificant impact of profitability. Model 2 explains 39.7\% of R \& D intensity differences between sample family firms. In model 3, family 
control is the only independent variable. $\mathrm{H} 3$ is verified by model 3 regression results. The $\mathrm{R} \& \mathrm{D}$ intensity in family firm with pyramid structure is less than the complementary sets by 0.01 . Similar results for control variables. Model 3 explains $40.4 \%$ of R \& D intensity differences between sample family firms.

2) The Moderating Effects of Institution Environments

Table 4 presents the estimation results of moderating effects of institution environments. All the models control for size, debt, age, profitability and growth and are estimated by pooled OLS. Institution and intersection term are added to the model. Specifically, adding institution and institution * family ownership in model 4 whose independent variable is family ownership. The result suggests

Table 4. The moderating effects of institution environments.

\begin{tabular}{|c|c|c|c|}
\hline Variables & Model 4 & Model 5 & Model 6 \\
\hline Family Ownership & $\begin{array}{c}0.010^{* * *} \\
{[3.71]}\end{array}$ & & \\
\hline Family Management & & $\begin{array}{c}0.007^{\star * *} \\
{[8.55]}\end{array}$ & \\
\hline Family Control & & & $\begin{array}{c}-0.009^{* * *} \\
{[-10.04]}\end{array}$ \\
\hline Constant & $\begin{array}{c}0.039^{* * *} \\
{[6.34]}\end{array}$ & $\begin{array}{c}0.041^{\star * *} \\
{[6.83]}\end{array}$ & $\begin{array}{c}0.042^{* * *} \\
{[7.12]}\end{array}$ \\
\hline Institution & $\begin{array}{c}0.001^{\star * *} \\
{[5.82]}\end{array}$ & $\begin{array}{c}0.001^{\star * *} \\
{[4.72]}\end{array}$ & $\begin{array}{c}0.001^{\star * *} \\
{[5.52]}\end{array}$ \\
\hline Institution * Family Ownership & $\begin{array}{c}-0.015^{\star * *} \\
{[-5.90]}\end{array}$ & & \\
\hline Institution * Family Management & & $\begin{array}{c}-0.006^{* * *} \\
{[-5.26]}\end{array}$ & \\
\hline Institution ${ }^{\star}$ Family Control & & & $\begin{array}{c}-0.006^{* * *} \\
{[-5.37]}\end{array}$ \\
\hline Size & $\begin{array}{c}-0.001^{\star * *} \\
{[-4.01]}\end{array}$ & $\begin{array}{c}-0.002^{\star * *} \\
{[-4.83]}\end{array}$ & $\begin{array}{c}-0.001^{\star *} \\
{[-2.56]}\end{array}$ \\
\hline Debt & $\begin{array}{c}-0.024^{* * *} \\
{[-15.50]}\end{array}$ & $\begin{array}{c}-0.023^{\star * *} \\
{[-14.62]}\end{array}$ & $\begin{array}{c}-0.022^{\star * *} \\
{[-14.35]}\end{array}$ \\
\hline Age & $\begin{array}{c}-0.014^{* * *} \\
{[-11.86]}\end{array}$ & $\begin{array}{c}-0.013^{* * *} \\
{[-11.70]}\end{array}$ & $\begin{array}{c}-0.013^{* * *} \\
{[-11.08]}\end{array}$ \\
\hline Profitability & $\begin{array}{l}0.007 \\
{[1.19]}\end{array}$ & $\begin{array}{c}0.007 \\
{[1.20]}\end{array}$ & $\begin{array}{c}0.007 \\
{[1.23]}\end{array}$ \\
\hline Growth & $\begin{array}{c}-0.001^{\star *} \\
{[-1.98]}\end{array}$ & $\begin{array}{c}-0.001^{\star *} \\
{[-2.09]}\end{array}$ & $\begin{array}{c}-0.001^{*} \\
{[-1.78]}\end{array}$ \\
\hline $\mathrm{N}$ & 4773 & 4773 & 4773 \\
\hline F-value & 115.175 & 117.715 & 121.262 \\
\hline R Square & 0.396 & 0.401 & 0.408 \\
\hline Adjusted R Square & 0.392 & 0.398 & 0.405 \\
\hline
\end{tabular}

Note: ${ }^{*},{ }^{* *},{ }^{* * *}$ represent significant results associated with $\mathrm{P}<0.1, \mathrm{P}<0.05$, and $\mathrm{P}<0.01$. 
that family ownership has a significantly positive impact on R \& D (0.01) and such positive relationship between family ownership and $\mathrm{R} \& \mathrm{D}$ investment is weaker for firms in regions with better institutions environment $(-0.015)$. Adding institution and institution ${ }^{\star}$ family management in model 5 . Result shows positive impact of family management on $\mathrm{R} \& \mathrm{D}(0.007)$ and such impact is weaker under better institutions environment $(-0.006)$. Finally, model 6 referred to family control, includes institution and institution * family control. Contrary to model 4 and model 5 , model 6 presents the negative impact of family control on $\mathrm{R} \& \mathrm{D}(-0.009)$ and such impact is weaker under better institutions environment $(-0.006)$.

In sum, $\mathrm{H} 4 \mathrm{~b}, \mathrm{H} 5 \mathrm{a}$ and $\mathrm{H} 6$ are supported by estimation results. It can be interpreted that the positive impacts of family ownership and family management on $\mathrm{R} \& \mathrm{D}$ are weaker while the negative impact of family control is weaker in province with better institutions environment. Regarding the institution itself, it shows a consistent positive impact on $\mathrm{R} \& \mathrm{D}$ in mode 4,5 and 6 . For control variables in three models, size, debt, age and growth all have negative impacts $n R$ \& D under different significance thresholds, whereas insignificant impact of profitability. Model 4, 5 and 6 can explain 39.6\%, 40.1\% and 40.8\% R \& D intensity differences between sample firms respectively.

\section{Conclusion}

In this paper, two questions are investigated. One is whether governance structure can actually influence R \& D investment in Chinese family firms. Related hypotheses are proposed based on agency theory. The results provide some insightful conclusions. Controlling for size, debt, age profitability and growth, we find the positive impacts of family ownership and family management on R \& D and the negative impact of family control on R \& D. Finally, realizing the expropriation nature of the family control, minority shareholders may discount and refuse to invest in $\mathrm{R} \& \mathrm{D}$ proposed by family controlling shareholder. The other research question explored is whether the moderating effects of institution environments exist in my sample. Institution and intersection terms are added to the models. Controlling for size, debt, age profitability and growth, the positive impacts of family ownership and family management on R \& D are weaker while the negative impact of family control is weaker in province with better institutions environment. The institution shows a consistent positive impact on $\mathrm{R} \& \mathrm{D}$. The result might be justified by the fact that family firms have higher propensity to diffuse their share and hire non family CEO in better institution environment.

\section{Conflicts of Interest}

The authors declare no conflicts of interest regarding the publication of this paper.

\section{References}

[1] Block, J.H. (2012) R\&D Investments in Family and Founder Firms: An Agency 
Perspective. Journal of Business Venturing, 27, 248-265.

https://doi.org/10.1016/j.jbusvent.2010.09.003

[2] Ettlie, J.E. (1998) R\&D and Global Manufacturing Performance. Management Science, 44, 1-11. https://doi.org/10.1287/mnsc.44.1.1

[3] Barker III, V.L. and Mueller, G.C. (2002) CEO Characteristics and Firm R\&D Spending. Management Science, 48, 782-801. https://doi.org/10.1287/mnsc.48.6.782.187

[4] Ortega-Argile's, R., Piva, M., Potters, L. and Vivarelli, M. (2010) Is Corporate R\&D Investment in High-Tech Sectors More Effective? Contemporary Economic Policy, 28, 353-365. https://doi.org/10.1111/j.1465-7287.2009.00186.x

[5] Rogers, M. (2004) Networks, Firm Size and Innovation. Small Business Economics, 22, 141-153. https://doi.org/10.1023/B:SBEJ.0000014451.99047.69

[6] Baysinger, B. and Hoskisson, R.E. (1989) Diversification Strategy and R\&D Intensity in Multiproduct Firms. Academy of Management Journal, 32, 310-332.

[7] Linton, J.D., Walsh, S.T. and Morabito, J. (2002) Analysis, Ranking and Selection of R\&D Projects in a Portfolio. R\&D Management, 32, 139-148. https://doi.org/10.1111/1467-9310.00246

[8] David, P., O’Brien, J.P. and Yoshikawa, T. (2008) The Implications of Debt Heterogeneity for R\&D Investment and Firm Performance. Academy of Management Journal, 51, 165-181. https://doi.org/10.5465/amj.2008.30772877

[9] Chiao, C. (2002) Relationship between Debt, R\&D and Physical Investment, Evidence from US Firm-Level Data. Applied Financial Economics, 12, 105-121. https://doi.org/10.1080/09603100110102709

[10] Tribo, J.A., Berrone, P. and Surroca, J. (2007) Do the Type and Number of Blockholders Influence R\&D Investments? New Evidence from Spain. Corporate Governance: An International Review, 15, 828-842. https://doi.org/10.1111/j.1467-8683.2007.00622.x

[11] Lee, P.M., and O'neill, H.M. (2003) Ownership Structures and R\&D Investments of US and Japanese Firms: Agency and Stewardship Perspectives. Academy of Management Journal, 46, 212-225.

[12] Zahra, S.A. (2003) International Expansion of US Manufacturing Family Businesses: The Effect of Ownership and Involvement. Journal of Business Venturing, 18, 495-512. https://doi.org/10.1016/S0883-9026(03)00057-0

[13] Miller, D. and Breton-Miller, L. (2006) Family Governance and Firm Performance: Agency, Stewardship, and Capabilities. Family Business Review, 19, 73-87. https://doi.org/10.1111/j.1741-6248.2006.00063.x

[14] Astrachan, J.H. (2003) Commentary on the Special Issue: The Emergence of a Field. Journal of Business Venturing, 18, 567-572. https://doi.org/10.1016/S0883-9026(03)00010-7

[15] Zahra, S.A. (2005) Entrepreneurial Risk Taking in Family Firms. Family Business Review, 18, 23-40. https://doi.org/10.1111/j.1741-6248.2005.00028.x

[16] Lee, J. (2006) Family Firm Performance: Further Evidence. Family Business Review, 19, 103-114. https://doi.org/10.1111/j.1741-6248.2006.00060.x

[17] Schulze, W.S., Lubatkin, M.H. and Dino, R.N. (2003) Exploring the Agency Consequences of Ownership Dispersion among the Directors of Private Family Firms. Academy of Management Journal, 46, 179-194.

[18] Peng, M.W. and Jiang, Y. (2010) Institutions behind Family Ownership and Control in Large Firms. Journal of Management Studies, 47, 253-273. 
https://doi.org/10.1111/j.1467-6486.2009.00890.x

[19] Steier, L.P. (2009) Familial Capitalism in Global Institutional Contexts: Implications for Corporate Governance and Entrepreneurship in East Asia. Asia Pacific Journal of Management, 26, 513-535. https://doi.org/10.1007/s10490-008-9117-0

[20] Liu, W., Yang, H. and Zhang, G. (2012) Does Family Business Excel in Firm Performance? An Institution-Based View. Asia Pacific Journal of Management, 29, 965-987. https://doi.org/10.1007/s10490-010-9216-6

[21] Jensen, M.C. and Meckling, W.H. (1976) Theory of the Firm: Managerial Behavior, Agency Costs and Ownership Structure. Journal of Financial Economics, 3, 305-360. https://doi.org/10.1016/0304-405X(76)90026-X

[22] La Porta, R., Lopez de Silanes, F. and Shleifer, A. (1999) Corporate Ownership around the World. Journal of Finance, 54, 471-517. https://doi.org/10.1111/0022-1082.00115

[23] Claessens, S., Djankov, S. and Lang, L.H.P. (2000) The Separation of Ownership and Control in East Asian Corporations. Journal of Financial Economics, 58, 81-112. https://doi.org/10.1016/S0304-405X(00)00067-2

[24] Faccio, M. and Lang, L.H.P. (2002) The Ultimate Ownership of Western European Corporations. Journal of Financial Economics, 65, 365-395. https://doi.org/10.1016/S0304-405X(02)00146-0

[25] Holderness, C.G. (2009) The Myth of Diffuse Ownership in the United States. Review of Financial Studies, 22, 1377-1408. https://doi.org/10.1093/rfs/hhm069

[26] Fan, G., Wang, X. and Zhu, H. (2011) The Marketization Index of China: The Process of Regional Marketization Report 2011. 